\title{
Isolation and Characterization of CMCase Producing Bacteria for the Purpose of Converting Spent Mushroom Edible Canna Substrate into Organic Fertilizer
}

Phân lập và tuyển chọn chủng vi khuẩn sinh CMCase để tạo phân bón hữu cơ từ bã dong riềng sau trồng nấm

\author{
Nguyen Phuong Anh, Truong Thi Phuong, Tran Lien Ha, Dang Minh Hieu* \\ Hanoi University of Science and Technology, Hanoi, Vietnam \\ *Email: hieu.dangminh@hust.edu.vn
}

\begin{abstract}
Converting spent mushroom substrates into organic fertilizer helps to tackle the problem of pollution in edible canna starch processing villages and adds new value to the production chain of edible canna. To successfully turn the spent substrates into compost, there is certainly an indispensable role for cellulolytic microorganisms, in which Bacillus strains are always important. Several bacterial strains have been isolated from spent edible canna substrate after cultivation of monkey head mushroom in this study. Among isolated strains, the strain NDK5 has been selected exhibiting the highest cellulolytic activities with solubilization indexes of 6.14 and $18.3 \mathrm{~mm}$ for the ratio between the halo zone diameters and the colony diameters in the point cultivation method (SIratio) and the offset between the halo zone diameters and the agar hole diameters (SI offset), respectively. The highest CMCase activity was $4.29 \pm 0.071 \mathrm{U} / \mathrm{ml}$. Morphological, physiological, biochemical, and 16S rRNA sequence analyses (100\% homology with $B$. amyloliquefaciens sp. plantarum FZB42) were further carried out for the selected strain, leading to the identification of the strain as B. amyloliquefaciens sp. plantarum NDK5 strain. In addition, NDK5 was proved to have a capacity for synthesizing indole-3-acetic acid, a plant growth hormone, on an L-tryptophan-containing medium. Trial incubation of spent mushroom edible canna-substrate with the strain NDK5 showed increases in several quality criteria of the waste after 20 days of incubation, that meet the standard criteria for bio-organic fertilizer according to TCVN 7185:2002.
\end{abstract}

Keywords: spent mushroom substrate, edible canna, CMCase, compost, Bacillus amyloliquefaciens

Tóm tắt

Sử dụng bã thải sau trồng nấm từ bã dong riềng để sản xuất phân bón hữu cơ đối với các làng nghề chế biến tinh bột dong riềng không chỉ góp phần giải quyết vấn đề ô nhiễm tại các làng nghề, mà còn tạo ra giá trị mới cho chuỗi sản phẩm từ dong riềng. Quá trình sản xuất phân bón, không thể thiếu vai trò rất quan trọng của các vi sinh vật phân giải cellulose, trong đó các chủng vi khuẩn Bacillus luôn có vị trí quan trọng. Trong nghiên cứu này, 26 chủng vi khuẩn phân giải cellulose đã được phân lập từ bã thải dong riềng sau trồng nấm đầu khỉ. Trong số các chủng phân lập, chủng NDK5 đã được lựa chọn có hoạt tính phân giải xenlulo cao nhất với tỷ lệ giữa đường kính vòng phân giải và đường kính khuẩn lạc trong phương pháp nuôi cấy chấm điểm (Slratio) là $6,14 \mathrm{~mm}$ và độ lệch giữa đường kính vòng phân giải và đường kính lỗ thạch trong phương pháp đục lỗ thạch (Sloffset) là 18,3 $\mathrm{mm}$. Hoạt độ CMCase cao nhất là 4,29 $\pm 0,071 \mathrm{U} / \mathrm{ml}$. Theo các kết quả về hình thái, sinh lý, sinh hoá và giải trình tự gen 16S rRNA (có 100\% tương đồng với chủng $B$. amyloliquefaciens sp. plantarum FZB42) thì chủng được đặt tên là chủng B. amyloliquefaciens sp. plantarum NDK5. Hơn nữa, chủng NDK5 đã được chứng minh có khả năng sinh tổng hợp indole-3-acetic acid, một loại hoc-môn sinh trưởng của thực vật, trên môi trường có chứa L-trypyophan. Thử nghiệm ủ bã thải dong riềng sau trồng nấm với chủng NDK5 cho thấy sự gia tăng một số chỉ tiêu chất lượng của bã sau 20 ngày ủ, đáp ứng tiêu chuẩn chất lượng cho phân bón hữu cơ vi sinh theo TCVN 7185:2002.

Từ khoá: bã thải sau trồng nấm, dong riềng, CMCase, phân bón, Bacillus amyloliquefaciens

\section{Introduction}

Edible canna was among major annual crops in uplands since the mid-1970s, especially in Northern Vietnam where is home to many craft villages processing starch from edible canna [1]. In recent years, the management of waste residues from edible canna from these villages is a challenging environmental issue. Among solutions to the management of waste from edible canna, using the waste residues as substrates for mushroom cultivation, or turning them into bio-fertilizer for crops are of great interest, recently [2-4]. On the other hand, edible canna substrate can be used to produce activated carbon [5], fibers and animal feeds, etc [6].

Macro-fungi, or mushrooms, have been widely known for their ability to decompose cellulosic and

ISSN 2734-9381

https://doi.org/10.51316/jst.148.etsd.2021.31.3.3

Received: August 3, 2018; accepted: July 9, 2021 
lignocellulosic wastes by releasing a high amount of exoenzymes [7]. The spent mushroom substrates (SMS), which is a byproduct after mushroom cultivation, thus is believed to produce a range of physical properties tailored to meet the requirements of different horticultural crops [7,8]. Wastes after mushroom cultivation, which contain minerals, phosphorous, high mash and carbon/nitrogen ratio, and porosity, have also been pointed out to be suitable materials for the production of bio-fertilizers and planting materials [9,10]. Recently, SMS was suggested using for soil amendment, and as a physicochemical strategy preventing and controlling soil and water contamination by pesticides [11].

Composting, generally, is the process that involves the biological activities of microbes to decompose wastes yielding fertilizer. The initial substrates usually contain high amounts of starch, cellulose, and hemicellulose as the major carbohydrates, which are gradually degraded by exoenzymes from mushrooms during cultivation. During composting, the spent substrates will be further degraded by amylolytic and cellulolytic bacteria to produce easy-uptake products for plants. The group of specific bacteria using in composting, besides stimulating plant growth by producing enzymes to convert nutrients into forms that are suitable for plant use, does nitrogen fixation, mediate the fungal growthsuppression, and produce plant growth hormones $[12,13]$.

Table 1. Compositions of spent edible canna substrate after cultivation of monkey head mushroom (Hericium erinaceus)

\begin{tabular}{|c|c|c|c|}
\hline No. & Composition & $\begin{array}{c}\text { Proportion } \\
\text { (\%, dry } \\
\text { weight) }\end{array}$ & $\begin{array}{c}\text { Method for } \\
\text { determination }\end{array}$ \\
\hline 1 & Minerals & 7.82 & $\begin{array}{c}\text { TCVN } \\
4327: 2007\end{array}$ \\
\hline 2 & Nitrogen & 0.25 & $\begin{array}{c}\text { TCVN 4327- } \\
2: 2011\end{array}$ \\
\hline 3 & Phosphorus & 0.07 & $\begin{array}{c}\text { TCVN } \\
1525: 2001\end{array}$ \\
\hline 4 & Starch & 4.37 & EC 152/2009 \\
\hline 5 & Cellulose & 2.36 & $\begin{array}{c}\text { TCVN } \\
4329: 2007\end{array}$ \\
\hline 6 & Hemicellulose & 8.92 & $\begin{array}{c}\text { AOAC } \\
973.18 .01\end{array}$ \\
\hline
\end{tabular}

With the aim to isolate a bacterium for the composting of spent mushroom edible canna substrate, in this study, we reported on the isolation of a bacterial strain from edible canna substrate residues after cultivation of monkey head mushroom (Hericium erinaceus). The isolated strain was characterized and classified by molecular techniques with 16S rRNA gene, which identified the strain as Bacillus amyloliquefaciens sp. Plantarum NDK5. Physiological study of the strain also indicated common characteristics of Bacillus bacteria.

\section{Materials and Methods}

\subsection{Isolation and Selection of Cellulolytic Bacterial Strain}

One gram (1g) of spent edible canna substrate after cultivation of monkey head mushroom (Hericium erinaceus) obtained from the Center for Research and Development of Mushroom, Agricultural Genetics Institute, Hanoi was suspended in a $250-\mathrm{ml}$ flask containing $90 \mathrm{ml}$ of NB medium (Peptone $10 \mathrm{~g} / \mathrm{l}$, meat extract $10 \mathrm{~g} / 1$, and $\mathrm{NaCl} 5 \mathrm{~g} / \mathrm{l}$ ), following incubation at $37{ }^{\circ} \mathrm{C}$ for 48 hours in a rotary incubator (Memmert, Germany) to enrich microbial populations. The substrate initial compositions were analyzed at VINACERT (A certification organization in Vietnam accredited by Assurance Services International) and described in table 1 . The flask, after 48 hours, was heated up to $70{ }^{\circ} \mathrm{C}$ for 15 minutes before left to ambient temperature, which is followed by the isolation and screening of cellulolytic bacterial strains on Hans agar selective medium consisting of constituents: $\mathrm{K}_{2} \mathrm{HPO}_{4} 0.5 \mathrm{~g} / 1, \mathrm{KH}_{2} \mathrm{PO}_{4} 0.5 \mathrm{~g} / 1,\left(\mathrm{NH}_{4}\right)_{2} \mathrm{SO}_{4} 1.0 \mathrm{~g} / 1$, $\mathrm{MgSO}_{4} .7 \mathrm{H}_{2} \mathrm{O} 0.1 \mathrm{~g} / 1, \mathrm{CaCl}_{2} 0.1 \mathrm{~g} / 1, \mathrm{NaCl} 6.0 \mathrm{~g} / 1$, yeast extract $0.1 \mathrm{~g} / 1$, carboxymethyl cellulose (CMC) $10 \mathrm{~g} / \mathrm{l}$, and agar $15 \mathrm{~g} / \mathrm{l}$; the $\mathrm{pH}$ was adjusted to 6.5 before sterilization, by pour plate technique. After $48 \mathrm{~h}$ of incubation at $37{ }^{\circ} \mathrm{C}$, a plate containing discrete colonies was stained with Lugol's solution (diluted iodine-potassium iodine solution) to visualize halo zones of digested CMC. The strains that produced halo zones were picked up, sub-cultured in Hans agar medium, and preserved.

The selection of cellulolytic bacterial strain was based on the abilities of the isolated strains to solubilize CMC substrate on Hans agar media. It was determined in terms of solubilization index (SI), which was expressed below as either ratio $\left(\mathrm{SI}_{\text {ratio }}\right)$ between the halo zone diameters and the colony diameters in point cultivation method, or offsets ( $\mathrm{SI}_{\text {offset }}$ ) between the halo zone diameters and the agar hole diameters in punched agar method.

\section{$\mathrm{SI}_{\text {ratio }}=$ Halo zone diameter / Colony diameter \\ $\mathrm{SI}_{\text {offset }}=$ Halo zone diameter - Agar hole diameter}

The abilities of isolated strains to solubilize CMC substrate can also be expressed in CMCase activities $(\mathrm{U} / \mathrm{ml})$. The unit of CMCase was defined as the amount of enzyme to liberate an amount of reducing sugar which equals to $1 \mu \mathrm{mol}$ of sugar in 1 minute at $50{ }^{\circ} \mathrm{C}, \mathrm{pH} 5$. The method for determination of enzyme activity was followed an internal method (V11 - 93) of VINACERT approved and exclusively authorized by the Ministry of Agricultural and Rural Development (MARD) according to Decision No. 744/QĐ-TCTACN, dated July 11, 2017. Selection methods were also mentioned in a previous report of Võ and Cao in $2011[14]$. 


\subsection{Identification of Bacterial Strain}

Different morphological, physiological, and biochemical tests of the selected phosphate solubilizing bacterial isolate were carried out for identification as per the methods defined in Bergey's Manual of Determinative Bacteriology [15].

\subsection{Identification of Indole-3-Acetic Acid (IAA) Producing Capacity}

The method for determining the capacity for synthesizing IAA of the isolated strain was a standard method TCVN 10784:2015, which was conducted on L-tryptophan-containing Luria Bertani medium (Bacto-tryptone $10 \mathrm{~g} / \mathrm{l}$, L-tryptophan $1 \mathrm{~g} / \mathrm{l}, \mathrm{NaCl} 5 \mathrm{~g} / \mathrm{l}$, Yeast extract $5 \mathrm{~g} / \mathrm{l}$, and agar $20 \mathrm{~g} / \mathrm{l}, \mathrm{pH} 7.5$ ). The isolated strain is cultivated on the medium at $37{ }^{\circ} \mathrm{C}$ for 48 hours. When colonies formed, Salkowski test solution $\left(\mathrm{FeCl}_{3} \quad 0.5 \mathrm{M}, 15 \mathrm{ml} ; \mathrm{H}_{2} \mathrm{SO}_{4} 98 \%, 300 \mathrm{ml}\right.$, $\mathrm{H}_{2} \mathrm{O}, 500 \mathrm{ml}$ ) is introduced on the medium's surface. The presence of IAA will be indicated by a pinkish ring surround the bacterial colony.

\subsection{Conversion of Spent Mushroom Edible Canna Substrate into Fertilizer Using the Isolated Strain}

The strain was incubated in NB medium, $\mathrm{pH} 6.5$, at $37^{\circ} \mathrm{C}$, a rotation rate of $150 \mathrm{rpm}$ for 2 days, followed by centrifugation at $10.000 \mathrm{rpm}$ for 10 minutes to obtain cell mass. Collected cell mass was resuspended into NB medium and counted for cell density. Spent mushroom edible canna substrate was incubated with the strain at the density of $10^{4} \mathrm{CFU} / \mathrm{g}$ of waste in $2-\mathrm{kg}$ plastic bags under ambient temperature (which is $24-28^{\circ} \mathrm{C}$ at the time of this experiment) for 20 days. Samples of the edible canna materials before and after the incubation were taken for determination of several quality criteria according to TCVN 7185:2002 for fertilizers.

\subsection{S rRNA Gene Sequencing and Analysis of the Isolated Strain}

Extraction of bacterial DNA was conducted as follows: Pellet of $1 \mathrm{ml}$ of the culture was put into an eppendorf containing $0.5 \mathrm{ml}$ of TE and SDS buffer (TE buffer: $15 \mathrm{mM}$ Tris-HCl + $1 \mathrm{mM}$ EDTA, $\mathrm{pH} 7.5)$, and keep at room temperature for 10 minutes. Then adding lysozyme $50 \mu \mathrm{l} / \mathrm{ml}$ and Proteinase $\mathrm{K}$, the solution was mixed gently for 3 minutes and keep at $65{ }^{\circ} \mathrm{C}$ for $1 \mathrm{~h}$. After that amount of $0.15 \mathrm{ml}, \mathrm{CH}_{3} \mathrm{COOK}$ was added and centrifuged at $10000 \mathrm{rpm}$ for 15 minutes at $4{ }^{\circ} \mathrm{C}$. The DNA was collected by rinsing with ethanol $70 \%$ and keep in $30 \mu 1$ sterilized water.

Amplification of $16 \mathrm{~S}$ rRNA sequence of the isolated strain was performed by PCR reaction in a Thermal cycler (MJ Research PTC200). The reaction mixture $25 \mu \mathrm{l}$ consisted of $20 \mathrm{ng}$ of genomic DNA, 2.5U of Taq DNA polymerase, $5 \mu \mathrm{l}$ of $10 \mathrm{X}$ Taq buffer (100 mM Tris-HCl, $500 \mathrm{mM} \mathrm{KCl,} \mathrm{pH} \mathrm{8.3),} 200 \mu \mathrm{M}$ dNTP, 10 pmoles each universal primer (27 Forward:
5'AGAGTTTGATCCTGGCTCAG3'; 1496 Reverse: 5'TACGGTTACCTTGTTACGACTT3') and $2.0 \mathrm{mM}$ $\mathrm{MgCl}_{2}$ was used. Amplification included initial denaturation at $95{ }^{\circ} \mathrm{C}$ for 5 minutes, followed by 35 cycles of denaturation at $95{ }^{\circ} \mathrm{C}$ for 30 seconds, the annealing temperature of primers at $52{ }^{\circ} \mathrm{C}$ for 30 seconds, and extension at $72^{\circ} \mathrm{C}$ for 1 minute. A final extension at $72{ }^{\circ} \mathrm{C}$ for 15 minutes was used. Five $\mu$ of the amplified product was then analyzed by submarine agarose gel electrophoresis in $1.2 \%$ agarose gel with ethidium bromide at $8 \mathrm{~V} / \mathrm{cm}$ and the PCR product was visualized under Gel doc/UV transilluminator. The amplified PCR product was gel purified using the QIAGEN gel extraction kit. A total of $100 \mathrm{ng} / \mu \mathrm{l}$ concentration of $16 \mathrm{~S}$ rRNA amplified product was used for the sequencing with the $27 \mathrm{~F}$ primer.

The 16S rRNA sequences were compared and aligned with sequences deposited in the NCBI GenBank database using BLAST [16] and Ribosomal Database Project II (RDP II) for identification of bacteria. The sequences were aligned using CLUSTAL X [17].

\section{Results and Discussion}

\subsection{Isolation and Selection of Bacterial Strain for High Cellulolytic Activity}

In the present study, samples collected from spent mushroom substrate were heated up to $70{ }^{\circ} \mathrm{C}$ for 15 minutes, and bacterial strains were screened and isolated on Hans agar selective medium. As a result, 26 strains were isolated, in which 5 strains showed highly potent CMCase activities. Figure 1 showed morphological characteristics of cells and colonies of the isolated strains. Figures $1 \mathrm{a}$ and $1 \mathrm{~b}$ indicated that the 5 potent strains, named NDK5, NDK4, NR6, LC2, and NR6, all can produce extracellular CMCase.

Further selection for the strain of the highest capacity of CMCase synthesis was conducted based on the determination of cellulose solubilization indexes and comparison of CMCase activities pointed out that the strain, named NDK5, showed the highest potent with the $\mathrm{SI}_{\text {ratio }}, \mathrm{SI}_{\text {offset }}$ and CMCase activity of 6.14, $18.3 \mathrm{~mm}$, and $4.29 \pm 0.071 \mathrm{U} / \mathrm{ml}$, respectively, which were the highest among isolated strains (Table 2). The strain NDK5, therefore, was selected for further characterization and study. Morphological study of the selected strain, NDK5, indicated rod-shaped cell, endospore production, and spore located in the center of the cell. The morphology of the strain's colonies showed opaquely white colonies with the wrinkled surface, a serrated edge, middle core, and large halo zone (Figure 1c and 1d). These morphological characteristics all indicated common characteristics of Bacillus bacteria. A previous study on the screening of cellulolytic microorganisms on soil medium, which isolated different Bacillus sp. including B. subtilis, $B$. lichenniformis, and $B$. amyloliquefaciens, showed similar morphological characteristics [18]. 


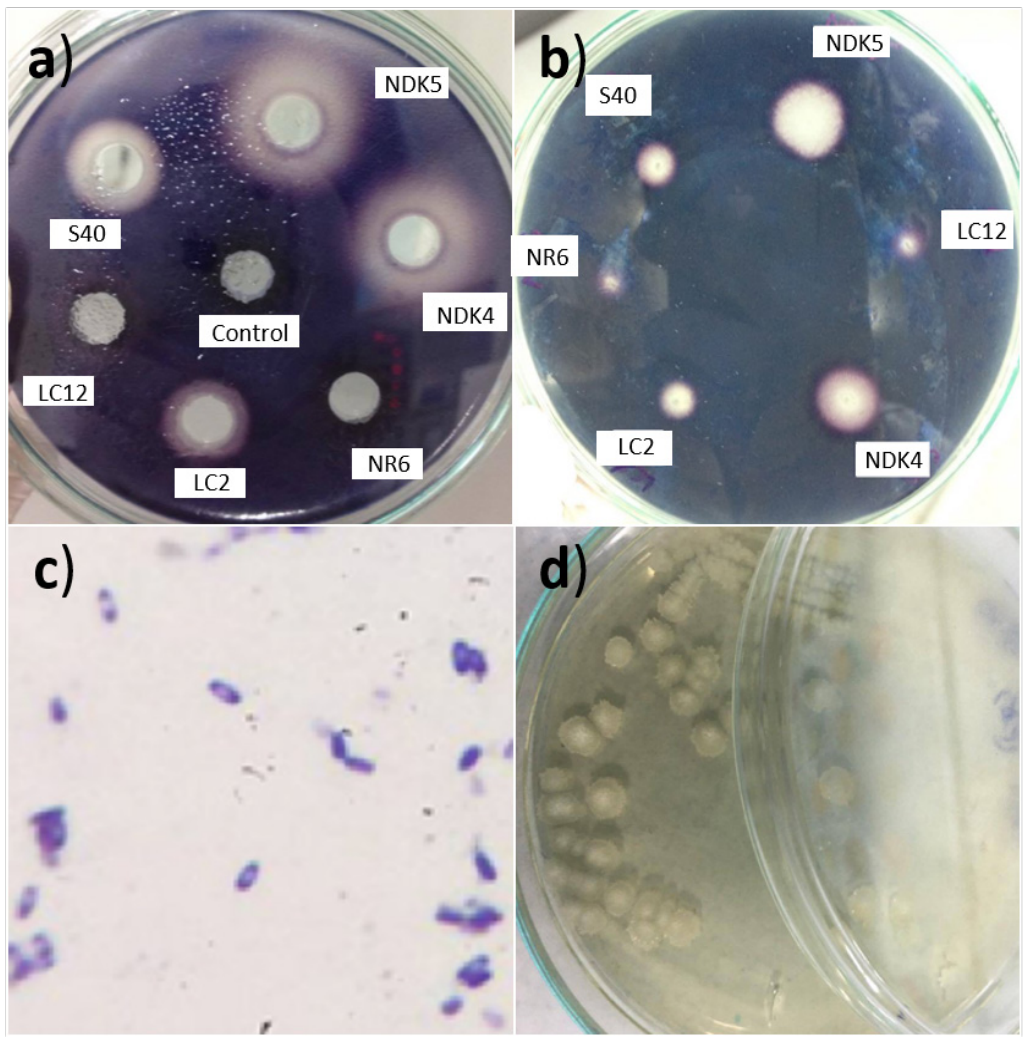

Fig. 1. Morphological and CMCase characteristics of the isolated cells and colonies. a, CMCase characteristics of the isolated strains in punched agar method; $b, C M C a s e$ characteristics of the isolated strains in point cultivation method; c, the cellular morphology of the strain NDK5; and d, the colonial morphology of the strain NDK5.

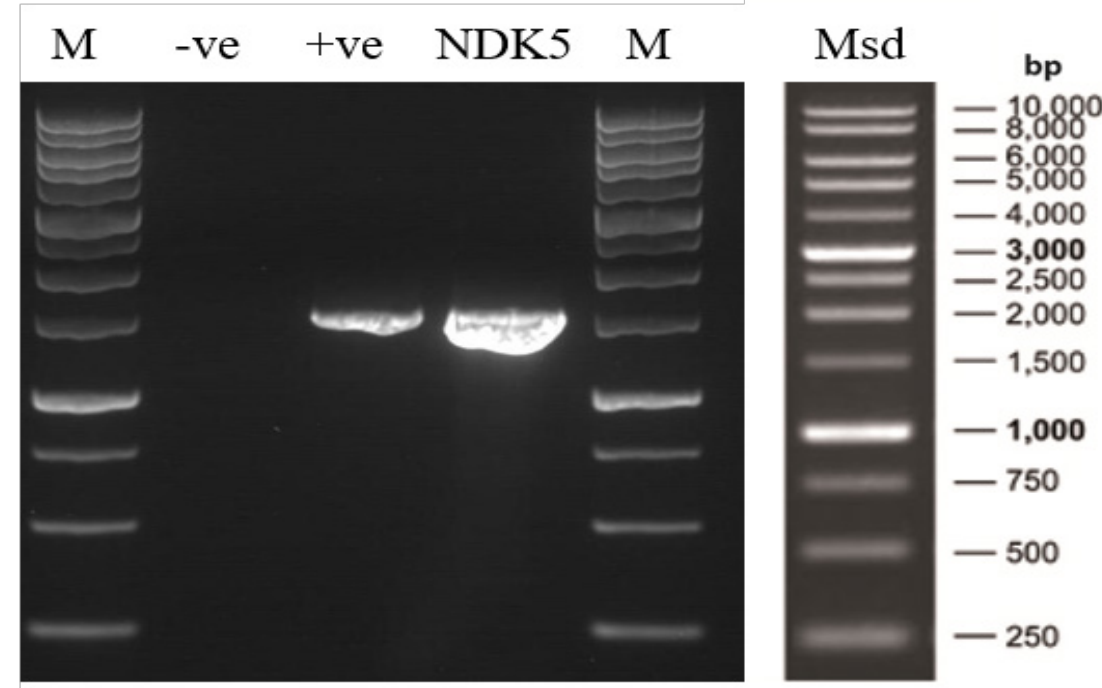

Fig. 2. PRC product of 16S rRNA sequence of NDK5. M, Msd, -ve, and +ve denote DNA marker, DNA marker standard, the PCR product of negative control, in which water was used instead of DNA template, and the PCR product of positive control, in which the $E$. coli DNA extract was used as a template, respectively.

\subsection{Physiological Characteristics of the Isolated Strain}

To further characterize the selected cellulolytic bacterium, NDK5, several biochemical tests were performed. All physiological results showed consistency with many phenotypic characteristics of the genus Bacillus sp. (Table 3). Considering all together physiological, morphological, and biochemical characteristics of the strain NDK5, this bacterium could be preliminarily identified as Bacillus sp. 
Table 2. Cellulolytic characteristics of the isolated strains

\begin{tabular}{|c|c|c|c|c|}
\hline No & Strain & \multicolumn{2}{|c|}{ Cellulolytic activities } & $\begin{array}{c}\text { CMCase } \\
\text { activity } \\
\text { (U/ml) }\end{array}$ \\
\cline { 3 - 5 } & & $\begin{array}{c}\text { Point } \\
\text { cultivatio } \\
\text { n (SI } \text { ratio })\end{array}$ & $\begin{array}{c}\text { Punched } \\
\text { agar } \\
\text { (SI }_{\text {offset, }} \\
\text { mm) }\end{array}$ & \\
\hline 1 & NDK4 & 5.75 & 13.71 & $\begin{array}{c}3.27 \pm \\
0.036\end{array}$ \\
\hline 2 & NDK5 & 6.14 & 18.30 & $\begin{array}{c}4.29 \pm \\
0.071\end{array}$ \\
\hline 3 & NR6 & 2.16 & 6.35 & $\begin{array}{c}1.30 \pm \\
0.068\end{array}$ \\
\hline 4 & LC2 & 3.77 & 8.12 & $\begin{array}{c}1.90 \pm \\
0.095\end{array}$ \\
\hline 5 & S40 & 3.87 & 9.80 & $\begin{array}{c}2.06 \pm \\
0.049\end{array}$ \\
\hline
\end{tabular}

Table 3. Physiological and biochemical characterization of the isolated bacterial strain (Bacillus sp. NDK5)

\begin{tabular}{|l|c|}
\hline Characteristics & $\begin{array}{c}\text { Bacterial } \\
\text { isolate }\end{array}$ \\
\hline Cell morphology & Rod \\
\hline Gram staining & - \\
\hline Mobility & + \\
\hline Catalase activity & - \\
\hline Lysine decarboxylase activity & - \\
\hline Ornithine decarboxylase activity & - \\
\hline Arginine dihydrolase activity & + \\
\hline Urease activity & - \\
\hline$\beta$-Galactosidase activity & + \\
\hline Haemolysis & - \\
\hline Indole production test & - \\
\hline H2S production test & + \\
\hline Voges-Proskauer test & + \\
\hline Citrate utilization test & - \\
\hline Utilization of carbon source & - \\
\hline D-Xylose & - \\
\hline Sucrose & - \\
\hline D- Mannitol & - \\
\hline Glucose & - \\
\hline Lactose & - \\
\hline+ indicates presence or positive & - \\
\hline - indicates absence or negative & - \\
\hline
\end{tabular}

\subsection{Molecular Identification of the Isolated Strain}

To further identify the selected bacterial strain, NDK5, the 16S rRNA gene of the strain was extracted and amplified, followed by $16 \mathrm{~S}$ rRNA sequencing. The extracted sequence was confirmed on agarose gel showing a band of around $1500 \mathrm{bp}$ (Figure 2). The sequencing result of the acquired $16 \mathrm{~S}$ rRNA indicated a sequence of around $1460 \mathrm{bp}$. BLAST search analysis of the 16S rRNA sequence of the selected strain was carried out that showed a sequence identity of $100 \%$ with $B$. amyloliquefaciens sp., B. subtilis sp., $B$. vallismortis DSM11031, and $B$. mojavensis IFO15718 strains. Comparative analysis of the most similar sequences by constructing a phylogenic tree indicated that the selected train has the closest relation to the $B$. amyloliquefaciens sp. plantarum FZB42 strain (Figure 3). The selected strain, thus, was assigned as B. amyloliquefaciens sp. plantarum NDK5.

B. amyloliquefaciens have been isolated and long been used as good plant growth-promoting rhizobacteria. Yuan and colleagues in 2013 proved that using the bio-fertilizer which contains the strain B. amyloliquefaciens sp. NJN-6 can significantly reduce the incidence of Fusarium wilt and promote the banana plant growth compared to that for the normal fertilizer [19]. The fertilizer containing the strain NJN-6 was further confirmed to significantly reduce the incidence of Panama disease caused by Fusarium oxysporum sp. cubense infection on banana, the major cause for loss in banana plantation worldwide, resulting in a doubled yield. In addition, the strain NJN-6 was proved to alter the rhizobacterial community by establishing beneficial strains that dominated the microbial community and decreased pathogen colonization in the banana rhizosphere [20]. Another plant disease, Fusarium head blight (FHB) caused by infection with Fusarium graminearum, was showed able to be controlled by B. amyloliquefaciens JCK-12 strain by several pathways including an inhibitory effect on $F$. graminearum spore germination, increased sensitivity of $F$. graminearum to fungicides, and potential reduction of trichothecenes mycotoxin production [21]. A recent study has pointed out that the isolated strain $B$. amyloliquefaciens IUMC7 can provide antimicrobial activity against Ralstonia solanacearum, a bacterial pathogen that causes bacterial wilt in a wide range of host plants including potato, tomato, eggplant, banana, ginger, tobacco, sweet pepper, rose and soybean [22]. Not only producing antimicrobial activity, $B$. amyloliquefaciens sp. also showed nematocide activity by producing the dipeptide cyclo(d-Pro-I-Leu) in the bacterial culture for control of Meloidogyme incognita, the root-knot nematode, by significantly inhibiting the hatching of eggs causing the mortality of its secondstage juveniles [23]. 


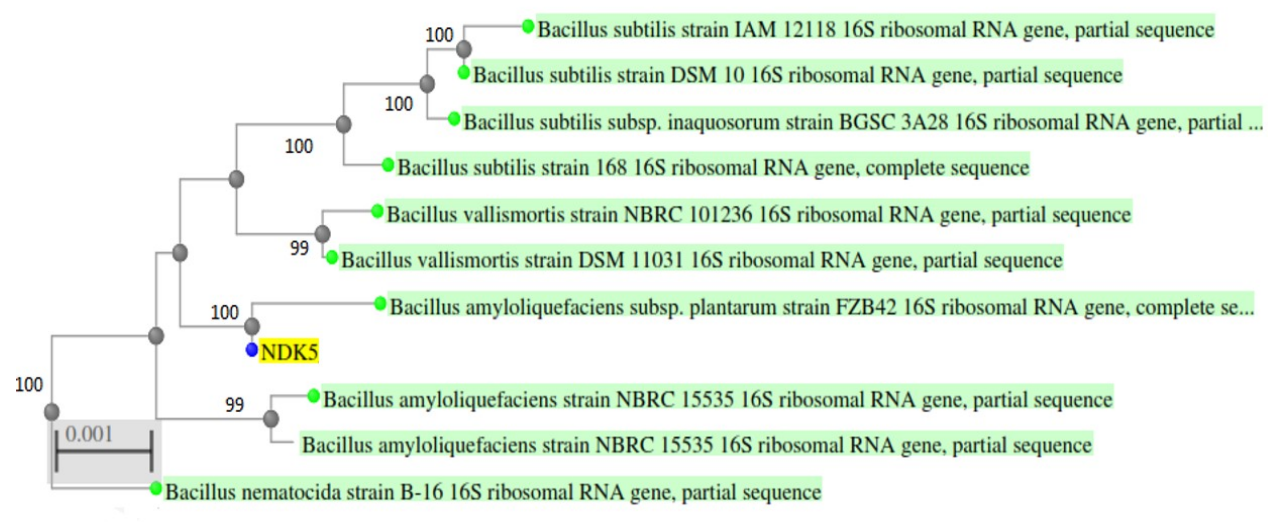

Fig. 3. Phylogenetic tree showing the evolutionary position and relationship of NDK5 strain with other bacterial isolates (complete sequence comparison).

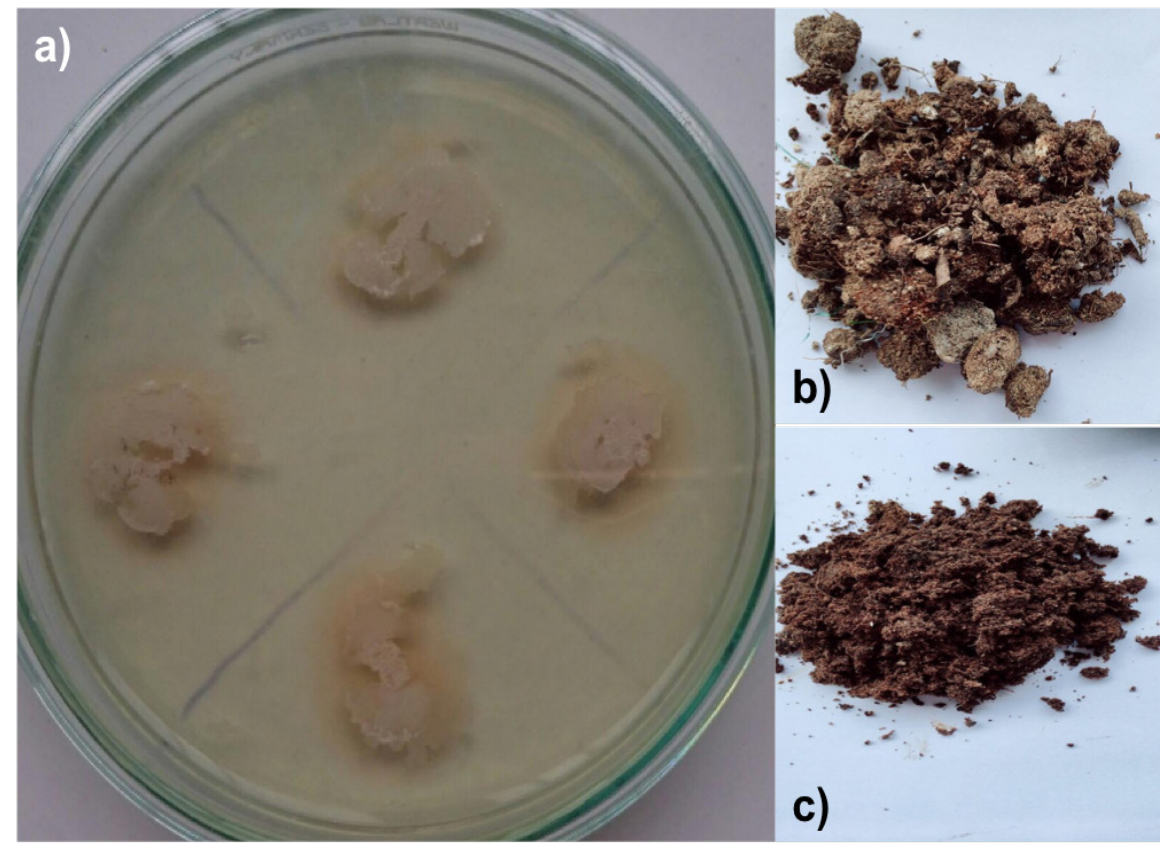

Fig. 4. The possibility of the isolated strain NDK5 for fertilizer production from spent mushroom substrate. a) IAA producing capacity of the isolated strain; b) and c) the spent mushroom edible canna substrate before and after 20 days of incubation, respectively.

\subsection{Production of Indole-3-Acetic Acid and Conversion of Spent Mushroom Edible Canna Substrate by the Isolated Strain}

The benefits of $B$. amyloliquefaciens to plants illustrated with not only the activities against bacterial pathogen and nematode that cause lethal diseases on crops but also the ability to synthesize plant growthhormone such as tryptophan-dependent indole-3acetic acid (IAA), auxin. A study on a root-associated bacterium, B. amyloliquefaciens SQR9 has indicated increased IAA production by SQR9, resulting in growth enhancement in cucumber [24]. Another study on genome analysis of $B$. amyloliquefaciens sp. plantarum UCMB5113 has proved the existence of the two genes putative IAA acetyltransferase (YsnE) and putative nitrilase (YhcX) involving the tryptophan dependent IAA synthesis in UCMB5113 and showed growth promotion on Arabidopsis thaliana Col-0 by UCMB5113 [25]. Interestingly, the isolated strain in this study, B. amyloliquefaciens sp. plantarum NDK5, also indicated a capacity of IAA production on Luria Bertani medium containing L-tryptophan. It was showed by a pinkish ring surround its colony when interacting with the Salkowski test solution (Figure 4a). This result makes the strain NDK5 more valuable to its future application as the cellulolytic bacterial strain for producing bio-fertilizer from spent Edible canna substrate, in particular, and other cellulose-rich substrates, in general. 
Table 4. The determined quality criteria of spent mushroom Edible canna-waste before and after the incubation

\begin{tabular}{|l|c|c|c|}
\hline Criteria & Original waste & $\begin{array}{c}\text { Waste after 20 days } \\
\text { incubation }\end{array}$ & TCVN 7185:2002 \\
\hline $\mathrm{pH}$ & 7,2 & 7,5 & $6,0-8,0$ \\
\hline Total organic matters, \% & 20,05 & 28,09 & $>22$ \\
\hline Total nitrogen, \% & 0,36 & 1,05 & $>2,5$ \\
\hline Total phosphorus, \% & n.a & 0,18 & $>2,5$ \\
\hline Total effective postasium, \% & n.a & 0,97 & $>1,5$ \\
\hline Lead, mg/kg dry weight & 2,7 & 2,6 & $<200$ \\
\hline Cadmium, mg/kg dry weight & n.d & n.d & $<2,5$ \\
\hline $\begin{array}{l}\text { n.a-not applicable } \\
\text { n.d-not detected }\end{array}$ & & & \\
\hline
\end{tabular}

To further confirm the possibility of using the isolated strain to convert spent mushroom edible canna substrate into fertilizer for crops, the substrate was incubated with the strain NDK5 at the density of $10^{4}$ $\mathrm{CFU} / \mathrm{g}$ of the waste for 20 days. The structures of the waste before and after the incubation were different, observing that, after 20 days of incubation, the waste became smoother with dark brown color, and smaller and shorter fibers (Figure $4 \mathrm{~b}$ and $4 \mathrm{c}$ ). Several quality criteria of the original waste and the waste after incubation were determined and compared in table 4 . All criteria determined for the waste after 20 days of incubation with the isolated strain meet the standard criteria for bio-organic fertilizer according to TCVN $7185: 2002$. Total nitrogen increased from 0.36 to $1.02 \%$. This result suggested the potential of being used of the isolated strain NDK5 in the production of organic fertilizer from spent mushroom edible canna substrate. Diallo and colleagues had shown that adding B. subtilis JCM $1465 \mathrm{~T}$ into composting process increases total nitrogen from 0.82 to $1.24 \%$ [26]. More experiments needed in order to exploit the potential of the strain NDK5 for converting spent mushroom substrates into compost for agricultural uses.

\section{Conclusion}

Several cellulolytic bacterial strains have been successfully isolated from the spent edible canna substrate after the cultivation of monkey head mushroom. From the isolated strains, the strain NDK5 has been selected exhibiting the strongest cellulolytic characteristics expressed as the $\mathrm{SI}_{\text {ratio }}$ of $6.14, \mathrm{SI}_{\text {offset }}$ of $18.3 \mathrm{~mm}$, and CMCase activity of $4.29 \pm 0.071 \mathrm{U} / \mathrm{ml}$. Morphological analyses suggested that the strain belongs to the genus Bacillus. Analyses of various physiological, biochemical tests and $16 \mathrm{~S}$ rRNA sequencing identified the selected strain as $B$. amyloliquefaciens sp. plantarum NDK5. The strain NDK5 further was confirmed to produce IAA, a plant growth hormone, on a medium containing Ltryptophan. In addition, spent mushroom edible canna substrate incubating with the strain NDK5 for 20 days showed increases in several quality criteria, those meet the standard criteria for bio-fertilizer according to
TCVN 7185:2002, suggesting the potential of the isolated strain for producing organic fertilizer from spent mushroom substrates. Works on the NDK5's metabolism and its actual capacity for converting spent mushroom substrates into compost are among the targets of our future study.

\section{Acknowledgements}

This work was funded by the project no. ĐT.08.17/CNSHCB supported by Vietnam Ministry of Industry and Commerce. The authors also acknowledge supports from all students and members of the Laboratory of Microbiology - Biochemistry Molecular Biology.

\section{References}

[1] F. Clement, J. M. Amezaga, D. Orange, D. T Tran, The impact of government policies on land use in Northern Vietnam: an institutional approach for understanding farmer decisions. IWMI Research Report, vol. 112, art. no. $21,2007$.

https://doi.org/10.3910/2009.112.

[2] N. N. Nguyen, V. C. Nguyen, T. L. Le, and L. H. Tran, Research on using arrowroot waste to grow white oyster mushrooms (Pleurotus florida). Vietnam Journal of Science and Technology, vol. 16, no. 5, 2017, pp. 54-58, (original text in Vietnamese).

[3] P. H. Nguyen, and T. T. H. Chu, Investigation of the pollution status and the waste reusing ability in trade village Duong Lieu, Hoai Duc, Hanoi, J. Viet. Env. vol. 3 , no. 2, 2012, pp. 87-91. https://doi.org/10.13141/jve.vol3.no2.pp87-91.

[4] T. H. Tran, Study on the treatment of arrowroot waste as bio-organic fertilizer in Da Bac district - Hoa Binh province, Thesis, National Academy of Agrriculture, Hanoi, Vietnam, 2011, (original text in Vietnamese).

[5] $\mathrm{L} . \mathrm{Vu}$, Research on using waste residues from the production of tapioca starch and arrowroot to make activated carbon for application in environmental treatment, Thesis, University of Natural Science, Hanoi, Vietnam, 2012, (original text in Vietnamese).

[6] M. V. Capiña, and V. L. L. Capiña, Edible canna (Maranta Arundinacea): Starch extraction, processing, and by-products utilization, in the 4th International 
Conference on Civil, Environment and Waste Management (CEWM-17), Manila, Phillipine, 2017, pp. 240-244.

[7] M. N. Owaid, I. A. Abed, and S. S. S. Al-Saeedi, Applicable properties of the bio-fertilizer spent mushroom substrate in organic systems as a byproduct from the cultivation of Pleurotus spp., Inf. Process. Agric., vol. 4, 2017, pp. 78-82.

https://doi.org/10.1016/j.inpa.2017.01.001.

[8] G. E. Barrett, P. D. Alexander, J. S. Robinson, and N. C. Bragg. Achieving environmentally sustainable growing media for soilless plant cultivation systems A review., Sci. Hortic., vol. 212, 2016, pp. 220-234. https://doi.org/10.1016/j.scienta.2016.09.030.

[9] N. T. Phan, Research on the solution for spent mushroom substrate in the area of Da Nang city. Thesis, Da Nang University, Da Nang, Vietnam, 2016, (original text in Vietnamese).

[10] T. L. Nguyen, Research on the treatment of spent mushroom abalone waste as a growing medium for vegetables. Thu Dau Mot University Journal of Science, vol. 1, no. 32, 2017, pp. 174-180, (original text in Vietnamese).

[11] J. M. Marín-Benito, M. J. Sánchez-Martín, and M. S. Rodríguez-Cruz, Impact of spent mushroom substrates on the fate of pesticides in soil, and their use for preventing and/or controlling soil and water Contamination: A Review, Toxics, vol. 4, 2016, Art. no. 17.

https://doi.org/10.3390/toxics4030017.

[12] S. Sarkar, S. Pal, and S. Chanda, Optimization of a vegetable waste composting process with significant thermophilic phase. Procedia Environemental Sciences, vol. 35, 2016, pp. 435-440.

[13] J. Pathma, and N. Sakthivel, Microbial diversity of vermicompost bacterial that exhibit useful agricultural traits and waste management potential, SphingerPlus, vol 1, 2012, art. no. 26.

[14] V. P. Q. Vo, and N. D. Cao. Isolation and identification of cellulose-degrading bacteria, Can Tho University Journal of Science, vol. 18, 2011, pp. 177-184, (original text in Vietnamese).

[15] J. G. Holt, N. R. Krieg, P. H. A. Sneath, J. T. Stanley, S. T. Williams, Bergey's Manual of Determinative Bacteriology, 9th ed., Williams \& Wilkins, Baltimore, USA, 1994.

[16] S. F. Altschul et al.. Gapped BLAST and PSI-BLAST: a new generation of protein database search programs. Nucleic Acids Res, vol. 25, 1997, pp. 3389-3402.

[17] J. D. Thompson et al., The CLUSTAL_X windows interface: flexible strategies for multiple sequence alignment aided by quality analysis tools. Nucleic Acids Res., vol. 25, 1997, pp. 4876 -4882.

[18] A. Amore, O. Pepe, V. Valentino, L. Birolo, C. Giangrande, and V. Faraco, Industrial waste based compost as a source of novel cellulolytic strains and enzymes, FEMS Microbiol. Lett., vol. 339, 2013, pp. 93-101.

https://doi.org/10.1111/1574-6968.12057.

[19] J. Yuan, Y. Ruan, B. Wang, J. Zhang, R. Waseem, Q. Huang, and Q. Shen, Plant growth-promoting rhizobacteria strain Bacillus amyloliquefaciens NJN6-enriched bio-oganic fertilizer suppressed Fusarium wilt and promoted the growth of banana plants, J. Agric. Food Chem., vol. 61, no. 16, 2013, pp. 37743780.

https://doi.org/10.1021/jf400038z.

[20] C. Xue, C. R. Penton, Z. Shen, R. Zhang, Q. Huang, R. Li, Y. Ruan, and Q. Shen, Manipulating the banana rhizosphere microbiome for biological control of Panama disease, Sci Rep, vol. 5, 2015, Art. no. 11124. https://doi.org/10.1038/srep11124.

[21] K. Kim, Y. Lee, A. Ha, J-I. Kim, A. R. Park, N. H. Yu, H. Son, G. J. Choi, H. W. Park, C. W. Lee, T. Lee, YW. Lee, and J-C. Kim, Chemosensitization of Fusarium graminearum to chemical fungicides using cyclic lipopeptides produced by Bacillus amyloliquefaciens strain JCK-12, Front. Plant Sci., vol. 8, 2017, Art. no. 2010.

https://doi.org/10.3389/fpls.2017.02010.

[22] K. Sotoyama, K. Akutsu, and M. Nakajima, Suppression of bacterial wilt of tomato by soil amendment with mushroom compost containing Bacillus amyloliquefaciens IUMC7, J Gen Plant Pathol, vol. 83, 2017, pp. 51-55. https://doi.org/10.1007/s10327-016-0690-7.

[23] Q. Jamal, J. -Y. Cho, J. -H. Moon, S. Munir, M. Anees, and K. Y. Kim, Identification for the first time of Cyclo(d-Pro-1-Leu) produced by Bacillus amyloliquefaciens $\mathrm{Y} 1$ as a nematocide for control of Meloidogyne incognita, Molecules, vol. 22, 2017, Art. no. 1839.

https://doi.org/10.3390/molecules22111839.

[24] Y. Liu, L. Chen, N. Zhang, Z. Li, G. Zhang, Y. Xu, Q. Shen, and R. Zhang, Plant-microbe communication enhances auxin biosynthesis by a root-associated bacterium, Bacillus amyloliquefaciens SQR9, Mol. Plant-Microbe Interact., vol. 29, no. 4, 2016, pp. 324330.

https://doi.org/10.1094/MPMI-10-15-0239-R.

[25] A. Niazi, S. Manzoor, A. Asari, S. Bejai, J. Meijer, and E. Bongcam-Rudloff, Genome analysis of Bacillus amyloliquefaciens subsp. plantarum UCMB5113: A rhizobacterium that improves plant growth and stress management, PLoS ONE, vol. 9, no. 8, 2014, Art. no. e104651. https://doi.org/10.1371/journal.pone.0104651.

[26] N. D. Diallo, M. MBengue, M. NGuer, M. Kâ, E. Tine, and C. T. Mbaye, Composting of sugar cane bagasse by Bacillus strains, Afr. J. Biotechnol., vol. 16, no. 3, 2017, pp. 113-123.

https://doi.org/10.5897/AJB2015.14998. 